\title{
MiCHAŁ JEŻOWSKI
}

Akademia Ekonomiczna w Poznaniu

\section{SPÓŁKA EUROPEJSKA - NOWA FORMA WYKONYWANIA DZIAŁALNOŚCI UBEZPIECZENIOWEJ}

\section{WSTĘP}

Zgodnie $\mathrm{z}$ ustawą o dzialalności ubezpieczeniowej ${ }^{1}$ warunkiem koniecznym podjęcia i prowadzenia działalności ubezpieczeniowej w Polsce jest przyjęcie jednej z dwóch form prawnych, a mianowicie formy spólki akcyjnej lub towarzystwa ubezpieczeń wzajemnych.

Dodatkowo zagraniczne zakłady ubezpieczeń, pochodzące spoza obszaru Unii Europejskiej mogą wykonywać działalność ubezpieczeniową w Polsce poprzez swój odział główny, natomiast Unijni ubezpieczyciele mogą wykonywać działalność ubezpieczeniową na trenie Rzeczypospolitej w formie oddziału lub w inny sposób niż przez oddział w ramach swobodnego przeplywu uslug ubezpieczeniowych.

Od dnia 8 października 2004 r. na Unijnym, a więc także Polskim rynku ubezpieczeniowym będą mogły prowadzić działalność zakłady ubezpieczeń zorganizowane w formie Spółki Europejskiej (SE). Tego dnia wchodzi bowiem w życie Rozporządzenie Rady (WE) nr 2157/2001 z dnia 8 października 2001 r. w sprawie statutu spólki europejskiej $(\mathrm{SE})^{2}$ (zwane dalej „Rozporządzeniem o statucie

\footnotetext{
${ }^{1}$ Ustawa z dnia 22 maja 2003 r. Dz.U. Nr 124, poz. 1154.

${ }^{2}$ Dz.U. WE L 294 z 10.11.2001 s. 1-21.
} 
SE”), które powołuje supranacjonalną formę spółki akcyjnej spólkę europejską. Niezbędnym wzbogaceniem regulacji Rozporządzenia jest Dyrektywa 2001/86/WE Rady z 8 października 2001 r. uzupełniająca statut spółki europejskiej w odniesieniu do zaangażowania pracowników ${ }^{3}$.

Celem niniejszego opracowania jest po pierwsze przybliżenie nowej formy podejmowania i prowadzenia dzialalności ubezpieczeniowej po drugie próba określenia ekonomicznych i prawnych konsekwencji dla zakładów ubezpieczeń w Polsce wprowadzenia do unijnego obrotu prawnego formy spólki europejskiej.

Dodatkowo należy podnieść, że ze względu na ograniczone ramy opracowania przedmiotem rozważań będą tylko charakterystyczne cechy spółki europejskiej ${ }^{4}$. W szczególności na uboczu pozostanie cała problematyka udziału pracowników w strukturach i funkcjonowaniu ubezpieczeniowej SE, a konsekwencje wprowadzenia SE dla zakładów ubezpieczeń w Polsce zostaną li tylko zarysowane.

\section{CHARAKTERYSTYKA SPÓEKI EUROPEJSKIEJ}

1. Spółka europejska w ogólności

Zgodnie z art. 1 i 4 Rozporządzenia o statucie SE, spółka europejska będzie posiadać osobowość prawną i występować w obrocie pod własną firmą z obligatoryjnym dodatkiem „SE”. Ma to być klasyczna spółka kapitałowa. Jej kapitał podzielony będzie na akcje i wyrażony w euro, przy czym minimalna wartość kapitału akcyjnego ma wynosić 120.000 euro - o ile ustawodawstwo państwa gdzie będzie mieścić się siedziba spółki nie przewiduje wyższej minimalnej wartości kapitału

\footnotetext{
${ }^{3}$ Dz.U. WE L 294 z 10.11.2001 str. 22-32.
}

${ }^{4}$ Szczególowo na temat spółki europejskiej patrz: J. LoRENC, Spótka Europejska a przepisy polskie, «Rejent»11.6 (2001), s. 114-147; M. MINAs, Spółka europejska w pracach komisji Wspólnot Europejskich, «KPP» 5.1 (1996). s. 65-92; K. OPLUsTIL, Europejska spótka akcyjna. Teksty aktów prawnych z omówieniem, Warszawa 2002. 
akcyjnego. Na podstawie art. 5 Rozporządzenia o statucie SE do zagadnień związanych z kapitałem SE, jego utrzymaniem, a także zmianami będzie się stosować przepisy, które miałyby zastosowanie do spólek akcyjnych ze statutową siedzibą w Państwie Członkowskim, w którym zarejestrowana będzie SE. Natomiast art. 7 Rozporządzenia o statucie SE stanowi, iż statutowa siedziba spółki europejskiej powinna znajdować się na terytorium Wspólnoty, w tym samym Państwie Członkowskim, w który znajduje się siedziba zarządu. Dodatkowo Państwo Czlonkowskie może zobowiązać SE zarejestrowaną na jego terytorium do zlokalizowania siedziby zarządu i statutowej siedziby w tym samym miejscu. Zgodnie zaś z art. 12 Rozporządzenia o statucie SE, każdą SE rejestruje się w rejestrze Państwa Czlonkowskiego, w którym ma mieć ona swoją statutową siedzibę, określonym przez prawo tego Państwa Członkowskiego zgodnie z art. 3 pierwszej dyrektywy Rady 68/151/EWG z dnia 9 marca 1968 r. w sprawie koordynacji gwarancji, jakie są wymagane w Państwach Czlonkowskich od spólek w rozumieniu art. 48 akapit drugi ${ }^{5}$ Traktatu o Wspólnocie Europejskiej, w celu uzyskania ich równoważności w całej Unii oraz dla zapewnienia ochrony interesów zarówno wspólników jak i osób trzecich. Rejestracja SE i jej wykreślenie z rejestru ogłasza się w celach informacyjnych w Dzienniku Urzędowym Wspólnot Europejskich.

Na podstawie art. 10 Rozporządzenia o statucie spółki europejskiej, jeżeli ten akt nie stanowi w pewnych przypadkach inaczej, Spółka Europejska powinna być traktowana w każdym Państwie Członkowskim UE tak, jak rodzima spółka akcyjna.

\section{Istotne cechy spółki europejskiej}

Spółka europejska ma cechy strukturalne oraz wlaściwości wskazujące na jej europejski - ponadnarodowy charakter i stanowiące

Zgodnie $\mathrm{z}$ art. 48 akapit 2 - przez spółki rozumie się spółki prawa cywilnego lub handlowego, a także spółdzielnie oraz inne osoby prawne prawa publicznego lub prywatnego, z wyjątkiem spólek, których działalność nie jest nastawiona na osiąganie zysków. 
zarazem o jej odrębności od spólek akcyjnych zawiązywanych na podstawie norm systemów prawnych poszczególnych Państw Członkowskich UE. W tym miejscu wypada wskazać na następujące cechy:

- szczególne sposoby zakładania SE

- możliwość transgranicznego przeniesienia siedziby spółki z zachowaniem jej tożsamości podmiotowej!

- prawo wyboru sposobu zarządzania (system dualistyczny, system monistyczny) ${ }^{6}$.

\section{Zakładanie SE}

Zasadniczo są cztery sposoby założenia spólki europejskiej, przy czym żaden z nich nie polega na zawiązaniu spólki od podstaw. Natomiast będziemy mieć do czynienia ze zmianami strukturalnymi istniejących już „spółek narodowych”. Procesy przekształceń i fuzji będą zachodzić na postawie art. 15-37 Rozporządzenia o statucie SE, a także - o tyle, o ile nie będzie to stało w sprzeczności z tym aktem - na podstawie prawa, które stosuje się do spółek akcyjnych w Państwie Członkowskim, w którym zakładana spółka europejska ma mieć swoją statutową siedzibę ${ }^{7}$. W przypadku SE z planowaną siedzibą w Polsce w grę wchodzą odpowiednie przepisy K.s.h.

1. Powstanie SE w wyniku łączenia się spółek. (fuzja transgraniczna)(Art. 2 ust 1, 17-31 Rozporządzenia o statucie SE)

Spólki akcyjne o statusie wspólnotowym ${ }^{8}$ mogą tworzyć SE przez łączenie się tych spółek, pod warunkiem, że przynajmniej dwie z nich podlegają prawu różnych Państw Członkowskich. W przypadku łączenia się spółek przez przejęcie, spółka przejmująca przyjmuje formę SE. W przypadku łączenia się spółek przez zawiązanie nowej spółki, SE będzie nowo powstałą spółką.

${ }^{6}$ Strukturę SE określono w art. 38-60 Rozporządzenia o statucie SE.

${ }^{7}$ Tak expressis verbis art. 15 Rozporządzenia o statucie SE.

${ }^{8}$ Chodzi o takie spółki, które powstały zgodnie z prawem Państwa Czlonkowskiego, mają statutową siedzibę i siedzibę zarządu na terytorium UE. 
2. Utworzenie grupy kapitałowej SE.(utworzenie holdingowej SE)(art. 2 ust 2, art. 32-34 Rozporządzenia o statucie SE)

Spółki akcyjne o statusie wspólnotowym i spółki z ograniczoną odpowiedzialnością o statusie wspólnotowym mogą utworzyć grupę kapitałową SE, pod warunkiem, że przynajmniej dwie $z$ nich podlegają prawu różnych Państw Członkowskich lub posiadają od co najmniej dwóch lat spółkę zależną, podległą prawu innego Państwa Członkowskiego lub oddział usytuowany w innym Państwie Członkowskim. Oczywiście spółki tworzące grupę kapitałową nie tracą bytu prawnego.

3. Powstanie spółki zależnej w formie SE. (utworzenie spółki filialnej SE)(art. 2 ust 3, art. 35 i 36 Rozporządzenia o statucie SE)

Spółki w rozumieniu drugiego akapitu art. 48 Traktatu o Wspólnocie Europejskiej mające status spółki wspólnotowej oraz inne osoby prawne prawa publicznego lub prywatnego o statusie wspólnotowym, mogą tworzyć spółki zależne SE, poprzez subskrybcję ich akcji, pod warunkiem, że przynajmniej dwie $z$ nich podlegają prawu różnych Państw Członkowskich lub posiadają od co najmniej dwóch lat spółkę zależną, podległą prawu innego Państwa Członkowskiego lub też oddział usytuowany w innym Państwie Członkowskim.

4. Przekształcenie istniejącej spółki akcyjnej w SE. (art. 2 ust 4, art. 37 Rozporządzenia o statucie SE)

Spółka akcyjna o statusie wspólnotowym może zostać przekształcona w SE, jeżeli od co najmniej dwóch lat posiada ona spó1kę zależną, podległą prawu innego Państwa Członkowskiego.

Dodatkowo należy wspomnieć, że na podstawie art. 3 ust. 1 Rozporządzenia o statucie SE w wyżej wskazanych procesach fuzji i przekształceń wziąć udział może także już istniejąca spółka europejska oraz, że na podstawie art. art. 3 ust. 2 tego aktu spółka europejska może zakładać także spółki - córki.

Przeniesienie statutowej siedziby SE

Przepisy dotyczące swobody przedsiębiorczości (Art. 43-48 TWE) nie są wystarczającą podstawą do swobodnego przenoszenia 
statutowej siedziby spólki prawa krajowego z jednego Państwa Członkowskiego Unii do drugiego bez zmiany jej tożsamości podmiotowej. Mimo, ze normy te przyznają osobom fizycznym oraz osobom prawnym - ,jak osobom fizycznym”, a więc na równych zasadach, prawo przenoszenia się do innego Państwa Członkowskiego, to zawsze wiąże się to ze zmianą prawa właściwego, co z kolei powoduje, że spółka traci swoją tożsamość podmiotową i w innym Państwie Członkowskim może zafunkcjonować tylko jako podmiot prawa tego Państwa9. Wiążących ustaleń w tym zakresie dokonał Europejski Trybunał Sprawiedliwości w sprawie 81/87 Daily Mail ${ }^{10}$.

W tym miejscu przypomnieć także należy, że zgodnie z polskim prawem na podstawie art. 459 K.s.h. rozwiązanie spółki akcyjnej powoduje, między innymi, uchwała walnego zgromadzenia o przeniesieniu siedziby spółki za granicę.

Tymczasem statutowa siedziba spółki europejskiej będzie mogła zostać przeniesiona do innego Państwa Członkowskiego, przy czym przeniesienie to nie wiąże się ani z likwidacją SE, ani $z$ utworzeniem nowej osoby prawnej. Transgraniczne przeniesienie siedziby SE odbywa się w drodze przewidzianej Rozporządzeniem o statucie SE skomplikowanej procedury określonej w art. 8 tego aktu.

Proces rozpoczyna się sporządzeniem planu przeniesienia i opublikowaniem go w Państwie Czlonkowskim, w którym mieści się dotychczasowa statutowa siedziba spółki. Czynności tych dokonuje zarząd (system dualistyczny) bądź tzw. organ administracyjny (system monistyczny). Plan przeniesienia powinien określać obecną firmę; siedzibę; numer pod którym SE jest zarejestrowana; proponowaną statutową siedzibę SE; proponowany Statut SE, gdy jest to właściwe, włącznie z jej nową firmą; wszelkie konsekwencje, jakie przeniesienie może mieć na uczestnictwo pracowników spółki; har-

' Spótka prawa krajowego, która chce przenieść siedzibę do innego Państwa powinna zostać zlikwidowana a w Państwie nowej siedziby powstanie nowa osoba prawna podległa jego prawu.

${ }^{10}$ Orzeczenie dostępne w angielskiej wersji językowej pod adresem internetowym: http://www.europa.eu.int/documents/ecj/index_pl.htm 
monogram przeniesienia; wszelkie prawa zagwarantowane w celu ochrony akcjonariuszy lub wierzycieli. Organ zarządzający lub administracyjny powinien także opracować sprawozdanie wyjaśniające i uzasadniające aspekty prawne i ekonomiczne przeniesienia oraz wyjaśniające konsekwencje przeniesienia tak dla akcjonariuszy jak i wierzycieli oraz pracowników. Akcjonariusze i wierzyciele spółki mają prawo przeglądać w statutowej siedzibie SE plan przeniesienia i sprawozdanie oraz zażądać otrzymania bezplatnych kopii tych dokumentów.

Zgromadzenie wspólników może podjąć uchwałę o przeniesieniu siedziby SE dopiero po upływie dwóch miesięcy, następujących po opublikowaniu planu. Nowa rejestracja może zostać dokonana dopiero wtedy, gdy zostanie przedstawione zaświadczenie oraz dowody, iż dokonano wszystkich czynności wymaganych do zarejestrowania spółki w państwie, w którym ma mieścić się jej nowa statutowa siedziba. Przeniesienie siedziby SE oraz wszelkie zmiany w statucie $z$ tym związane są skuteczne od daty zarejestrowania SE w rejestrze nowej statutowej siedziby. Po dokonaniu rejestracji nowej siedziby SE rejestr, który dokonal nowej rejestracji będzie zawiadamiać rejestr poprzedniej statutowej siedziby. Wykreślenie spółki ze starego rejestru będzie dokonane nie wcześniej niż z chwilą otrzymania zawiadomienia.

Prawo Państwa Członkowskiego może przewidywać, że przeniesienie statutowej siedziby spółki zarejestrowanej w tym Państwie Członkowskim, której skutkiem byłaby zmiana prawa właściwe go nie będzie skuteczne, jeżeli właściwy organ tego Państwa Członkowskiego wyrazi sprzeciw w tej sprawie w terminie dwóch miesięcy od opublikowaniu planu przeniesienia. W przypadku, gdy SE będzie podlegać nadzorowi krajowego finansowego organu nadzorczego ${ }^{11}$, to prawo do wniesienia sprzeciwu w sprawie przeniesienia statutowej siedziby przysługuje również temu organowi.

\footnotetext{
${ }^{11} \mathrm{~Np} .:$ nadzorowi sprawowanemu przez Komisję Nadzoru Ubezpieczeń i Funduszy Emerytalnych - co będzie miało miejsce w przypadku ubezpieczeniowej SE z siedzibą w Polsce.
} 
Ustawodawca europejski przewidział zakaz przeniesienia statutowej siedziby, jeżeli wobec danej spółki europejskiej toczy się postępowanie w sprawie rozwiązania, likwidacji, niewypłacalności lub tymczasowego wstrzymania płatności lub inne postępowanie o podobnym charakterze.

W celu ochrony wierzycieli wprowadzono domniemanie, zgodnie z którym co do dowolnej wierzytelności powstałej przed przeniesieniem statutowej siedziby do innego Państwa Członkowskiego, SE będzie uznana jako mająca statutową siedzibę w tym Państwie Członkowskim, w którym siedziba spółki była zarejestrowana przed przeniesieniem. Domniemanie to jest skuteczne nawet wtedy, kiedy postępowanie przeciwko tej spółce europejskiej zostało wszczęte po dokonaniu przeniesienia statutowej siedziby.

Zarządzanie i nadzór w SE - system monistyczny.

Zgodnie z art. 38 Rozporządzenia o statucie SE w spółce europejskiej zarządzanie oraz nadzór mogą być sprawowane w systemie dualistycznym (Art. 39-42 Rozporządzenia o statucie SE) bądź monistycznym (Art. 43-45 Rozporządzenia o statucie SE). W systemie dualistycznym w spółce europejskiej może funkcjonować tak zarząd jak i rada nadzorcza. Taki układ organów w spółce kapitałowej jest znajomy polskiemu prawu. W tym miejscu należy jedynie dodać, że przepisy Rozporządzenia o statucie SE nie przewidują rewolucyjnych rozwiązań, choć w pewnych przypadkach odbiegają od rozwiązań polskiego prawa spółek handlowych.

Istotne novum natomiast stanowi możliwość przyjęcia systemu monistycznego - nawet w tych państwach, których systemy prawne nie znają takiego rozwiązania. Tak więc w Polsce już wkrótce mogą rozpocząć działalność SE, gdzie zamiast zarządu i rady nadzorczej funkcję zarządcze i nadzorcze skupi w sobie organ zwany w Rozporządzeniu o statucie SE „organem administracyjnym”. Dlatego te $\dot{z}$ poniżej zaprezentowane zostaną założenia Rozporządzenia o statucie SE w zakresie systemu monistycznego.

Rozpocząć należy od wskazania, iż zgodnie z art. 43 ust. 4 Rozporządzenia o statucie SE w przypadku, gdy prawo danego Pan- 
stwa Czlonkowskiego nie przewiduje żadnych uregulowań dotyczących systemu monistycznego, Państwo Członkowskie może wprowadzić własne rozwiązania do krajowego sytemu prawnego w tym zakresie. Taka delegacja skierowana do ustawodawcy krajowego z natury rzeczy dotyczy tylko wydania przepisów „na użytek” regulacji sytemu monistycznego w spółce europejskiej

Tak więc zgodnie $\mathrm{z}$ art. 43 ust. 1 zd. 1 Rozporządzenia o statucie SE, organ administracyjny prowadzi sprawy SE. Członków organu administracyjnego powołuje walne zgromadzenie. Jednakże członkowie pierwszego organu administracyjnego mogą być już wskazani przez Statut. Tak liczba członków organu administracyjnego jak i zasady ją określające ustanawiane są także w Statucie spółki.

Organ administracyjny zbiera się w terminach ustanowionych w Statucie jednak powinien zebrać się przynajmniej raz na trzy miesiące, aby omówić bieżące sprawy spółki.

Na podstawie przepisów Rozporządzenia o statucie SE dotyczących tak sytemu dualistycznego jak i monistycznego (Art. 46-51 Rozporządzenia o statucie SE) przyjąć należy, że członkowie organu administracyjnego spółki powolywani są na okres ustanowiony w Statucie, jednakże nie przekraczający sześciu lat i zasadniczo mogą być powołani ponownie jeden raz lub więcej niż jeden raz. Statut SE może przewidywać, że spółka lub inna osoba prawna może zostać członkiem jednego z jej organów pod warunkiem, że prawo, które stosuje się do spółek akcyjnych w Państwie Członkowskim, w którym zarejestrowana jest SE nie stanowi inaczej. Zgodnie zaś $\mathrm{z}$ art. 18 § 1 K.s.h. członkiem zarządu, rady nadzorczej, komisji rewizyjnej albo likwidatorem może być tylko osoba fizyczna mająca pełną zdolność do czynności prawnych. Dlatego możliwość powolania do organu administracyjnego osoby prawnej nie dotyczy SE, które ewentualnie zlokalizują swoją siedzibę w Polsce.

Statut SE powinien wskazać rodzaje spraw spółki, w których dla podjęcia decyzji wymagana jest wyraźna uchwała organu administracyjnego.

Członkowie organu administracyjnego spółki europejskiej będą zobowiązani, nawet po ustąpieniu z urzędu, do nie ujawniania ja- 
kichkolwiek informacji dotyczących spółki, których ujawnienie mogłoby zaszkodzić jej interesom.

Członkowie organu administracyjnych SE ponoszą odpowiedzialność za straty lub szkody poniesione przez SE na skutek niedotrzymania przez nich zobowiązań, wynikających z ich obowiązków wobec SE, ustanowionych przez Statut lub inne akty prawne. W takim przypadku stosuje się przepisy wlaściwe spółkom akcyjnym w Państwie Członkowskim, w którym mieści się siedziba SE.

\section{Infrastruktura prawna SE}

Każda osoba prawna zawdzięcza swoje istnienie określonemu systemowi prawnemu, który jest jej statutem personalnym ${ }^{12}$. $\mathrm{Na}$ szczególną uwagę zasługuje ciekawa, aczkolwiek skomplikowana, piramida praw „rządzących” spółką Europejską. Otóż na podstawie art. 9 Rozporządzenia o statucie SE, spółka europejska działa w oparciu o:

I. przepisy Rozporządzenia o statucie SE,

II. w przypadku, gdy jest to wyraźnie określone w Rozporządzeniu, przepisy swojego statutu (rozumianego jako dokument zawiązania konkretnej spółki) lub

III. w sprawach nieuregulowanych Rozporządzeniem o statucie SE lub, w przypadku, gdy są one uregulowane w nim jedynie częściowo, w zakresie pozostawionym poza Rozporządzeniem:

1. przepisy prawa przyjęte przez Państwa Czlonkowskie w celu wprowadzenia w życie specjalnych środków wspólnotowych dotyczących konkretnie SE - chodzi przede wszystkim o przepisy implementujące Dyrektywę 2001/86/WE Rady z 8 października 2001 r. uzupełniającą statut spólki europejskiej w odniesieniu do zaangażowania pracowników,

2. przepisy prawa Państw Członkowskich, które mialyby zastosowanie do spółek akcyjnych, utworzonych zgodnie z prawem Państwa Członkowskiego, w którym SE ma swoją statutową siedzibę -

${ }^{12}$ Tak: M. Minas, op. cit. s. 65. 
w przypadku przyjęcia przez SE siedziby na terytorium Rzeczypospolitej Polskiej zastosowanie znajdą właściwe przepisy Kodeksu spółek handlowych ${ }^{13}$ o spółce akcyjnej;

3. przepisy swojego statutu, w taki sam sposób jak spółki akcyjne, utworzone zgodnie z prawem Państwa Czlonkowskiego, w którym SE ma swoją statutową siedzibę.

Dodatkowo ten sam artykuł stanowi, iż przepisy prawa ustanowione przez Państwa Czlonkowskie dotyczące konkretnie SE muszą być zgodne $z$ odpowiednimi dyrektywami, które stosuje się do spółek akcyjnych w Państwach Członkowskich UE. Jeżeli zaś charakter działalności prowadzonej przez SE uregulowany jest przepisami szczególnymi prawa krajowego, to przepisy te stosuje się w całości do SE. Tak więc, jeżeli SE będzie miała siedzibę w Polsce i będzie prowadzić działalność ubezpieczeniową, w pelni zastosowanie znajdą polskie, krajowe przepisy prawa ubezpieczeń gospodarczych tak ustrojowe, jak i te związane z podejmowaniem i prowadzeniem działalności ubezpieczeniowej.

\section{KONSEKWENCJE WPROWADZENIA SE}

DLA ZAKŁADÓW UBEZPIECZEŃ PROWADZĄCYCH DZIALALNOŚĆ UBEZPIECZENIOWA W POLSCE - ZARYS PROBLEMU

Już na samym początku należy zwrócić uwagę na fakt, że jak dotąd nie można było empirycznie zweryfikować wpływu pojawienia się spółki akcyjnej o charakterze ponadnarodowym na spółki akcyjne, ale o charakterze krajowym. Empiryczne badania nie są możliwe, ponieważ jeszcze nie powstała ani jedna SE, dlatego jedynym rozwiązaniem jest podjęcie próby przewidzenia możliwych stanów faktycznych i płynących z nich konsekwencji.

Inna kwestia wymagająca rozważenia w tym miejscu, to pytanie o zasadność rozstrzygania konsekwencji wprowadzenia SE

${ }^{13}$ Ustawa z dnia 15 września 2000 r. Kodeks spółek handlowych, Dz.U. Nr 94, poz. 1037 z późn. zm. 
dla ubezpieczycieli z punktu widzenia polskiego zakładu ubezpieczeń ${ }^{14}$. Wydaje się, że można podnieść zarzut zbyt wąskiego ujęcia problemu. Skoro bowiem będziemy mieć do czynienia z ponadnarodową formą podejmowania i prowadzenia działalności ubezpieczeniowej, to punkt widzenia powinien być zgola odmienny, a mianowicie badania powinny być prowadzone $\mathrm{z}$ punktu widzenia całej Unii, a nie tylko jednego Państwa Członkowskiego. Jednakże należy pamiętać, że będziemy świadkami bezprecedensowej sytuacji, oto powstaną bowiem podmioty, które będą mogły prowadzić stałą działalność we wszystkich krajach Unii przy wykorzystaniu jednego centrum zarządzającego i to bez konieczności przyjęcia reżimu pierwotnej lub wtórnej swobody przedsiębiorczości, a tym bardziej swobody świadczenia usług. Dlatego też wydaje się, że spojrzenie na nadchodzące zmiany z perspektywy polskiego zakładu ubezpieczeń mogą być nadzwyczaj cenne.

Punktem wyjścia dla rozważań na temat konsekwencji wprowadzenia spółki europejskiej dla ubezpieczycieli w Polsce jest próba odpowiedzi na pytanie o podstawy prawne dla rozpoczęcia w Polsce działalności ubezpieczeniowej przez SE.

Oczywiście trzeba rozważyć dwie sytuacje. Pierwsza to taka, w której mamy do czynienia z SE z siedzibą w Państwie Członkowskim Unii innym niz Polska. Druga zaś to taka, w której mamy do czynienia z SE z siedzibą w Polsce.

Jeśli chodzi o pierwszy przypadek to SE może prowadzić działalność w Polsce o tyle, o ile spełniła wszystkie wymogi do podjęcia działalności ubezpieczeniowej w kraju siedziby. Zgodnie bowiem $\mathrm{z}$ art. 9 ust. 3 Rozporządzenia o statucie SE - jeżeli charakter dzialalności prowadzonej przez SE uregulowany jest przepisami szczególnymi prawa krajowego, to przepisy te stosuje się w calości do SE. Jako podmiot prawa unijnego SE nabywa prawa i zaciąga zobowiązania na terenie całej Wspólnoty. To właśnie wspólnotowa

${ }^{14}$ Chodzi o takie spółki, które powstaly zgodnie z polskim prawem oraz mają statutową siedzibę i siedzibę zarządu na terytorium RP. 
osobowość prawna pozwoli prowadzić działalność ubezpieczeniową w całej Unii bez związania ramami wyznaczanymi przez prawo wewnętrzne Państw Członkowskich.

Biorąc pod uwagę art. 9 ust. 3 Rozporządzenia o statucie SE, w przypadku SE zlokalizowanej na terenie Polski, będzie ona mogła podjąć działalność ubezpieczeniową po spełnieniu wszystkich kryteriów przewidzianych przez polskie wewnętrzne prawo ubezpieczeń gospodarczych i również działać na terenie całej Unii bez ograniczeń.

Tak więc w jednym, jak i w drugim przypadku podstawy prawne podjęcia działalności ubezpieczeniowej znajdują się w ustawodawstwie Państwa Członkowskiego, które jest już w dużym stopniu zunifikowane i może ulec tylko dalszym procesom unifikacji. Zgodnie bowiem z klauzulą stand-still znajdującą swoją podstawę w art. 10 TWE, Państwa Członkowskie nie mogą zmieniać prawa dostosowanego raz do wymogów dyrektyw, ani wydawać przepisów, które sprzeciwiałyby się harmonizacji ${ }^{15}$.

Można więc latwo wykazać, że Polskie zakłady ubezpieczeń (o ile nie zostaną wchłonięte przez SE lub się nie przekształcą w SE o czym dalej) zyskają potężna konkurencję. Konkurencję, która w zakresie dzialalności ubezpieczeniowej podlegać będzie albo prawu polskiemu (ubezpieczeniowa SE z siedzibą w Polsce) albo prawu ubezpieczeń gospodarczych innego Państwa Członkowskiego Unii Europejskiej z możliwością prowadzenia działalności w calej Unii.

Wreszcie można zadać pytanie o wpływ na zakłady ubezpieczeń działające w Polsce, nieuchronnych - jak się wydaje - procesów fuzji i przekształceń związanych z tworzeniem spólek europejskich.

Polskie zakłady ubezpieczeń o tyle, o ile spełniają kryteria Rozporządzenia o statucie SE, będą brały udzial w tworzeniu spółek europejskich. Dotyczy to przede wszystkim spółek akcyjnych, ale wydaje się, że w przypadku tworzenie filialnej SE także towarzystw

${ }^{15}$ Tak: K. Oplustil, op. cit., s. 34,35. 
ubezpieczeń wzajemnych ${ }^{16}$. Polskie ubezpieczeniowe spółki akcyjne będące spółkami córkami mogą zniknąć z obrotu, ponieważ jest prawdopodobne, że zostaną wchłonięte przez nowo tworzone SE, które zlokalizują swoją siedzibę za granicą. Z drugiej strony może też się zdarzyć, że w wyniku fuzji i przekształceń powstaną SE, które zechcą zlokalizować swoją siedzibę na terenie Polski. Podstawowy wplyw na taką decyzję będzie miał stan konkurencyjności polskiego systemu prawnego ${ }^{17}$ i to nie tylko na poziomie prawa ubezpieczeń gospodarczych ale np.: w sferze podatkowej.

Tak więc spółka europejska to nie tylko potężna konkurencja, ale także nowe możliwości dla polskich zakładów ubezpieczeń. W literaturze ${ }^{18}$ przewiduje się wiele korzyści plynących z przyjęcia formy spółki europejskiej. Po przekształceniu lub połączeniu z zagranicznym zakładem ubezpieczeń i utworzeniu w ten sposób SE otworzą się nowe możliwości w zakresie zwiększenia efektywności i przyspieszenia w zarządzaniu, możliwość wyboru pomiędzy dualistycznym a monistycznym sposobem zarządzania, wreszcie możliwości transgranicznego przeniesienia siedziby statutowej z zachowaniem tożsamości podmiotowej czy zwiększenia atrakcyjności w sferze good will i prawa firmowego co w dziedzinie ubezpieczeń szczególnie istotne.

\section{PODSUMOWANIE}

Spółka europejska stanowi nową formę prawną podejmowania i prowadzenia działalności ubezpieczeniowej. Jest ona ponadnarodową osobą prawną, której funkcjonowanie ma oprzeć się na wspólnotowym akcie prawa wtórnego, ale także w dużej mierze na normach systemów prawnych Państw Członkowskich. Spółka europejska stanowi szansę na szybki rozwój dla wszystkich tych ubezpie-

\footnotetext{
${ }^{16}$ Jako formy prawnej objętej zakresem normy art. 48 akapit 2 TWE.

${ }^{17}$ Por. na ten temat: K. Oplustil, op. cit., s. 34, 35.

${ }^{18}$ Por. na ten temat: K. OpLustil, op. cit., s. 27-32.
} 
czycieli, których działalność wykazuje charakter transgraniczny. Polskie zakłady ubezpieczeń z pewnością zyskają silną ponadnarodowa konkurencję, ale także będą mogły wziąć udział procesach przekształceń i międzynarodowych połączeń.

\section{EUROPEAN COMPANY - A NEW FORM \\ of CONDUCTING INSURANCE ACTIVITY}

\section{Summary}

The primary aim of this article is to present legal regulations concerning creation and functioning of the European company as a legal form of conducting insurance activity.

A model of a European company has been created to allow a combination of the economic potentials of existing companies in different Member States and their reorganization, which is expected to decrease the costs and improve the management efficiency of insurance companies by eliminating the expensive multinational holding structures.

In this article the author attempts to present the consequences of introducing a European company in the insurance sector in Poland.

A European company gives a possibility of fast development for those insurance companies, the activities of which cross the borders. The Polish insurance companies will face a strong competition but at the same time they will have opportunities to witness and participate in the reforms of the system. 